\title{
Correction to: Indirect and direct routes to C-glycosylated flavones in Saccharomyces cerevisiae
}

Katherina Garcia Vanegas ${ }^{1}$, Arésu Bondrup Larsen², Michael Eichenberger ${ }^{2}$, David Fischer ${ }^{2}$,
Uffe Hasbro Mortensen ${ }^{1}$ and Michael Naesby ${ }^{2^{*}}$ (D)

\section{Correction to: Microb Cell Fact (2018) 17:107}

https://doi.org/10.1186/s12934-018-0952-5

Upon publication of this article [1], it was brought to our attention that revised Fig. 1 supplied by the author during proof correction was unfortunately not presented in the original version of the article. The revised Fig. 1 is given in this erratum.

The original article has been corrected. 


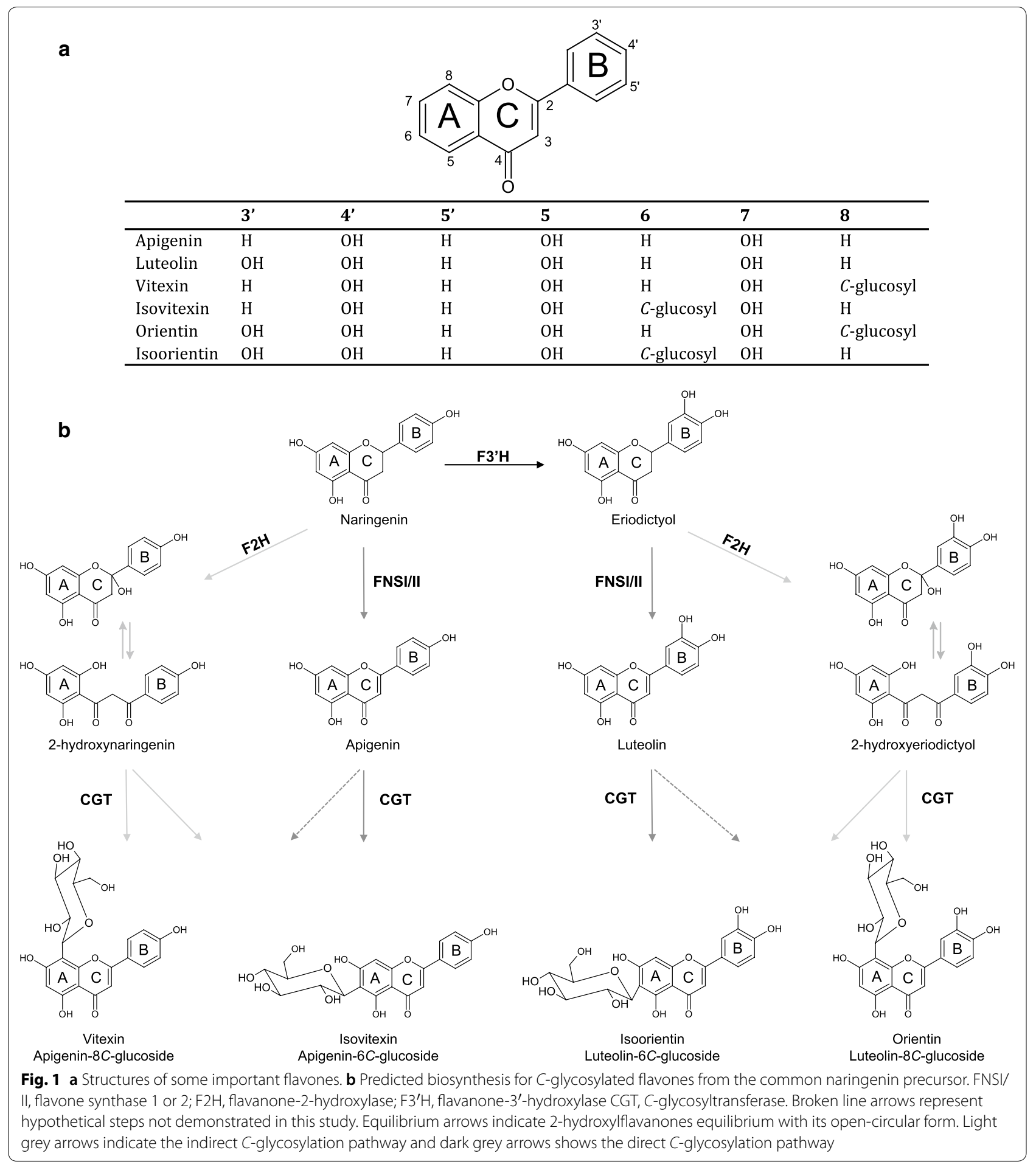

\section{Author details}

1 Department of Biotechnology and Biomedicine, Technical University of Denmark, Søltofts Plads, Building 223, 2800 Kgs Lyngby, Copenhagen, Denmark.

The original article can be found online at https://doi.org/10.1186/s1293

${ }^{2}$ Evolva SA, Duggingerstrasse 23, 4153 Reinach, Switzerland. 


\section{Publisher's Note}

Springer Nature remains neutral with regard to jurisdictional claims in published maps and institutional affiliations.

Published online: 28 July 2018

\section{Reference}

1. Vanegas KG, Larsen AB, Eichenberger M, Fischer D, Mortensen UH, Naesby M. Indirect and direct routes to C-glycosylated flavones in Saccharomyces cerevisiae. Microb Cell Fact. 2018;17:107. https://doi.org/10.1186/s1293 4-018-0952-5. 